\title{
Condition of Soil Fertility and Sensory Profile of Smallholder Robusta Coffee in Jember District
}

\author{
Niken Puspita Sari ${ }^{1 *}$ and Dwi Nugroho ${ }^{1)}$ \\ ${ }^{1)}$ Indonesian Coffee and Cocoa Research Institute, J1. PB. Sudirman 90, Jember, Indonesia \\ ${ }^{*}$ Corresponding author: niken.puslitkoka@gmail.com \\ Received: 4 February 2016 / Accepted: 27 July 2016
}

\begin{abstract}
Jember district is one of the centers for smallholder plantation of the Robusta coffee in East Java. However, there are still limited reports about environmental conditions, particularly soil fertility of existing smallholder plantations and its effect on coffee flavor. The purpose of this study was to investigate the effect of soil fertility on flavor of coffee in existing smallholder Robusta coffee plantations in Jember district. This research was carried out by survey method in several area of the smallholder Robusta coffee plantation in Jember. Evaluation of sensory profile was carried out using cup test organoleptic method based on Standard cupping method of the Specialty Coffee Association of America. Research locations as subdistricts were chosen by purposive sampling method, namely Panti, Silo, Rambipuji, Sukorambi, and Tanggul subdistricts. Results of this study showed that soil of the smallholder Robusta coffee plantation in research locations possessed low organic carbon content in Sukorambi subdistrict and medium concentration in other locations. Nitrogen content was low in all locations, potassium in Sumber Baru subdistrict was high whereas other locations were medium. Phosphorus availability was high in all locations. Calcium and magnesium were medium in Panti, Sukorambi, Sumber Baru, and Silo subdistricts. Soil acidity was low in all locations. Results of the sensory analysis of smallholder's Robusta coffee was from divided into three groups. First, categorized as fine Robusta coffee was smallholder's Robusta coffee samples obtained from Silo and Sukorambi subdistricts. Second, good quality Robusta coffee was from smallholder Robusta coffee samples from Panti and Sumber Baru subdistricts. Third, medium quality Robusta coffee was from smallholder's Robusta coffee from Tanggul subdistrict. Total scores of coffee testing from samples of Panti, Sukorambi, Sumber Baru, Tanggul, and Silo subdistrict were 79.8, 82.0, 79.9, 76.0, and 82.5 , respectively.
\end{abstract}

Keywords: coffee, Robusta, smallholder, Jember, soil fertility, flavor

\section{INTRODUCTION}

Indonesia is the fourth largest coffee producer in the world after Brazil, Colombia, and Vietnam. Climate and geographical location of this country are very supportive for the coffee plants to grow, meanwhile this commodity contribute to domestic revenues.
Indonesia is very suitable for Robusta and Arabica coffee plants as reflected by relatively even distribution of coffee areas from Sumatera to Papua, which causes different unique characteristics of coffee quality in each region.

There are several Robusta coffee major producers in Indonesia, including 
Lampung, Central Java, East Java, South Sumatera, Bengkulu, Bali, Nusa Tenggara Timur and Nusa Tenggara Barat (Kusmiati \& Windiarti, 2011). Jember is one of the areas producing Robusta coffee in East Java province. Actually, beside coffee, it is easy to find cocoa, rubber, sugar cane, and tobacco in Jember because this district has suitable climate and geographic location to support plantation crops. Total area of Robusta coffee plantations owned by smallholders in Jember district was 5,608 hectares, second largest after Malang district (Ditjenbun, 2010). Productivity of Robusta coffee in Jember was $840 \mathrm{~kg} / \mathrm{ha}$ which is slightly lower than average Robusta coffee's productivity in East Java (878 kg/ha). Meanwhile, marketing potential of Robusta coffee in this area was not optimum (Zahrosa, 2011), though environmental conditions in Jember are appropriate to improve its coffee production and marketing.

Coffee has distinctive characteristics compared to other crops. The nature of biannual bearing leads to the fluctuation of coffee production. The current climate change also affects and even tends to lower the coffee productivity. In addition to the climate change, soil fertility also determines coffee productivity. Survival of the coffee plants requires good soil fertility which is a very important factor to reduce the impact of the fluctuative coffee flowering cycle in each year. Coffee plants require good soil fertility for its survival, in which ideal soil contain $\mathrm{C}>2 \%$, $\mathrm{C} / \mathrm{N}$ ratio $10-12$, cation exchangable capacitiy $>15 \mathrm{me} / 100 \mathrm{~g}$, base saturation $>35 \%$, soil $\mathrm{pH}$ 5.5-6.5; N nutrient minimum $0.28 \%$, P Bray $132 \mathrm{ppm}$, exchangable $\mathrm{K} 0.50 \mathrm{me} / 100 \mathrm{~g}$, exchangable Ca $5.3 \mathrm{me} /$ $100 \mathrm{~g}$, exchangable Mg 1 me/100 g (Puslitkoka, 1998). Results of soil fertility study in 1987 carried out in Besuki areas (particularly in Jember) showed that in coffee plantations mainly dominated by mineral type $1: 1$ namely hydrates halloisite and kaolinite soil types (Wibawa, 1987). Meanwhile, recent research showed that soil types from east mountainside of Hyang Argopuro to west mountain-sideof Raung volcano were Inceptisol, Alfisol, and Entisol (Putra, 2006).

Differences in minerals content in soil resulted in different soil fertility. A report of Wibawa (1987) showed that the southern part of Besuki had lower fertility compared to northern part (Wibawa, 1987). However, information on relationship between soil fertility condition and flavor of the Robusta coffee derived from plantations in Jember is not known. Earlier research regarding the relation of the nutrient content of the soil with coffee sensory profiles related with focused on $\mathrm{Zn}$ deficiency, in which it was reported that $\mathrm{Zn}$ deficiency resulted in small beans and purplish colored bean and also reduced the decrease of the coffee flavor. Excessive of nitrogen (N) application content affected the quality and increase caffein content, whereas Fe deficiency resulted in yellowish coffee bean (Snoeck \& Lambot, 2004). A study conducted by Abdoellah et al. (2000) showed that there was a quadratic relationship between coffee flavor with climatic conditions, especially within dry months. Therefore, those kinds of studies are required as information on control or management of Robusta coffee plantations which have an impact on the increase of Robusta coffee productivity and flavor.

Specific characteristic of Jember smallholder coffee plantations is that they are grown in a limited area, particularly close to their houses. Usually, smallholder management of coffee plants is very minimal which means that fertilization, pest and disease control are rarely done. Thus, such conditions causing the smallholder plantations have different soil fertility compared to large plantations. Areas of Robusta coffee plantations in Jember 
change every year, but recently the area of smallholder Robusta coffee plantations tends to decline. Based on that background, this study was carried out to investigate current soil fertility condition and to evaluate sensory profiles of Robusta coffee of the smallholder farmers in Jember district.

\section{MATERIALS AND METHODS}

The research was conducted by survey in September 2014. Locations of this study were determined purposively in the Robusta production center areas in Jember district, namely Panti, Silo, Sukorambi, Rambipuji, and Tanggul subdistricts. Firstly, the study of the locations of smallholder plantation was carried out to obtain available information on coffee. Identification of the location was implemented by recording the location informations such as elevation, covered area, shade trees and litter thickness. Plant samples were taken at some points by grid method. The soil samples were taken in the depth of $0-20 \mathrm{~cm}$ by drilling the soil in four points around the sampled coffee tree. Collected soil samples were then mixed to be a composite sample represented the local conditions. One composite sample of soil represented a total area of 50-60 ha of Robusta coffee farms. The soil samples were coded refer to the observed sites an then analyzed at the
Laboratory of Soil Analysis of Indonesian Coffee and Cocoa Research Institute (ICCRI). The analyzed elements covered macro and micro nutrients such as $\mathrm{C}, \mathrm{N}, \mathrm{C} / \mathrm{N}, \mathrm{P}, \mathrm{K}, \mathrm{Ca}$, $\mathrm{Mg}, \mathrm{CEC}$, available P, S and pH. Environmental conditions such as types of shade trees were identified, and the litter thickness was measured.

\section{Sensory Evaluation}

Two kilograms of dry coffee beans were taken from each of the surveyed soil sampling location. Coffee bean processing was performed by dry process method which was usually conducted by Robusta coffee farmers. Sensory evaluation was conducted at Sensory Analysis Laboratory of ICCRI.

Samples for testing the sensory profile were obtained by roasting $150 \mathrm{~g}$ green bean coffee with Probat Roaster equipment. Coffee was roasted to reach medium roast level with color standard $65 \AA$ (Agtron scale No. 65). The roasted samples were then grinded using a coffee grinder. Brewing was done by taking $10 \mathrm{~g}$ ground coffee, and then poured with mineral water with temperature of $90-100^{\circ} \mathrm{C}$. Each sample was repeated five times (served in five bowls) to test uniformity. The testing was conducted by descriptive method, using a scoring system

Tabel 1. Selected locations for soil survey and bean quality assessment of the smallholder Robusta coffee in Jember district

\begin{tabular}{llccc}
\hline Subdistrict & \multicolumn{1}{c}{ Village } & Latitude & Longtitude & Topography \\
\hline Panti & Kemiri & -8.06620600 & 113.64309738 & Steep \\
Panti & Kemiri & -8.06663641 & 113.64648887 & Steep \\
Sukorambi & Karang Pring & -8.09727302 & 113.65869367 & Flat \\
Sumberbaru & Glagah & -8.02521514 & 113.37326079 & Flat \\
Sumberbaru & Sumber Gelang & -8.05435600 & 113.41204218 & Undulating \\
Tanggul & Darungan & -8.12890314 & 113.52893746 & Flat \\
Silo & Sidomulyo & -8.22441719 & 113.93175395 & Flat \\
Silo & Sidomulyo & -8.22345092 & 113.93491577 & Undulating \\
Silo & Garahan & -8.23075122 & 113.90151179 & Flat \\
\hline
\end{tabular}


developed by Lingle (1986a, 1986b) from the Specialty Coffee Association of America (SCAA). The tested samples were assessed by scoring between 1-10 in each character tested, except uniformity and sweetness characters. The observed flavor characters included fragrance and aroma, flavor, aftertaste (left impression in mouth after inhaling/ drinking coffee), salt/acid (quality and quantity of salty and sour taste), bitter/sweet (quality and quantity of bitter and sweet taste), mouthfeel (coffee viscosity level), uniformity (uniformity and stability of flavor in each bowl served), sweetness (presence of sweet taste), balance (balance of flavor, aftertaste, acidity and body as a whole), clean cup ('cleanliness' level of coffee flavor/ smell from non-coffee's), overall (panelist preference to the taste and aroma of coffee), and total score (the sum of each testing component value). Each tested sample also got comments from the panelists to describe the flavors which were not represented in the testing form. Data analysis was performed utilizing Pearson correlation analysis to correlate the soil nutrients with coffee flavor in the same location.

\section{RESULTS AND DISCUSSION}

Current soil fertility of coffee plantations in several subdistricts in Jember can be seen in Table 2. The analysis results showed that soil fertility in Panti subdistrict had the best soil fertility compared to Sukorambi, Sumber Baru, Tanggul, and Silo subdistricts. It was indicated by soil organic C content which was more than $3 \%$ in accordance with the minimum requirements for growing coffee plants. Other soil analysis results indicated that Panti subdistrict remained also possess higher content of $\mathrm{P}, \mathrm{K}, \mathrm{Ca}, \mathrm{Mg}$, and CEC parameters compared to others. Based on this analysis results, it appeared that the land management in Panti subdistrict was better than other subdistricts. Existence of other annual crops functioned as shade trees contributing to soil fertility improvement. Low soil fertility occured in Silo subdistrict. It was assumed that its low soil fertility was due to the coffee plantations location which was in the sloping topography where the erosion rate was higher, thus caused erosion on the layer of fertile soil. Further, the farmers tend to use lower dose of fertilizer so soil nutrients did not balance missing nutrients requirement after harvest time.

The value of $\mathrm{CEC}$ at each location varied. CEC describes the ability of soil to absorb and release nutrients from soil to plants. It means that the smaller the CEC value is, the lower the ability of coffee plants to absorb nutrients. CEC of coffee farm was at least $15 \mathrm{me} / 100 \mathrm{~g}$ soil. The test results of soil in the study showed that in Silo subdistrict, the CEC values were below the least value namely 9 me/100 g soil; whereas, the highest CEC value was in Panti subdistrict namely $26.77 \mathrm{me} / 100 \mathrm{~g}$ soil. At Silo subdistrict, efforts are necessary to improve CEC value due to Silo's slope contour with the height at the site at about $569 \mathrm{~m}$ asl. It means that the increase in CEC value is expected to minimize the risks of erosion and nutrient leaching in Silo subdistrict. CEC value increasing can be done by providing organic matter which is able to bind the soil in order to be more stable and rich in nutrients. Beside adding organic matter, efforts in soil and water conservation in Silo subdistrict should also be improved to increase soil fertility by reducing nutrients loss due to the soil runoff.

Based on Table 2, it can be seen that each location had different soil analysis results. Soil organic carbon is required at least 2\% for coffee plants (Surtinah, 2009), thus Panti, Sumber Baru, Tanggul, and Silo 
Table 2. Soil analysis results of soil samples obtained from smallholder Robusta coffee plantation in Jember district

\begin{tabular}{|c|c|c|c|c|c|c|c|c|c|c|}
\hline \multirow[t]{2}{*}{ Subdistrict } & $\mathrm{C}$ & $\mathrm{N}$ & $\mathrm{C} / \mathrm{N}$ & $\mathrm{K}$ & $\mathrm{Ca}$ & $\mathrm{Mg}$ & CEC & Available P & $S$ & \multirow[t]{2}{*}{$\mathrm{pH}\left(\mathrm{H}_{2} \mathrm{O}\right)$} \\
\hline & & $\%$ & & \multicolumn{4}{|c|}{$\mathrm{me} / 100 \mathrm{~g}$} & \multicolumn{2}{|c|}{ ppm } & \\
\hline Panti & 3.04 & 0.25 & 12 & 1.125 & 15.29 & 4.51 & 26.77 & 29.5 & 58 & 5.2 \\
\hline Sukorambi & 1.99 & 0.22 & 9 & 1.2 & 12.56 & 2.61 & 23.61 & 56 & 43 & 5.1 \\
\hline Sumber Baru & 2.44 & 0.24 & 10.5 & 1.91 & 11.64 & 2.85 & 21.89 & 16 & 35 & 5.3 \\
\hline Tanggul & 2.2 & 0.25 & 9 & 0.62 & 3.97 & 0.83 & 19.22 & 38 & 88 & 4.2 \\
\hline Silo & 2.00 & 0.21 & 10 & 0.59 & 5.02 & 0.80 & 9.99 & 184 & 74.33 & 4.8 \\
\hline
\end{tabular}

subdistricts had sufficient organic C content, whereas Sukorambi subdistrict had organic $\mathrm{C}$ lower than minimum requirement organic $\mathrm{C}$ for coffee plant. Organic $\mathrm{C}$ can be improved with application of organic matter in soil. Degradation of organic $\mathrm{C}$ could be resulted from land clearing till become agriculture land. Alley \& Vanlauwe (2009) reported that the decreasing may up to $1.65 \%$ throughout 20 years, therefore duration of land utilization which causes the level of $\mathrm{C}$ soil organic in Robusta coffee smallholder in Jember was lower.

Nitrogen of soil in each observed location were low. Nitrogen content is considered as low if the value of nitrogen below than $0.28 \%$. The low value of nitrogen indicated that the input of nitrogen such as inorganic fertilizer to soil was low. It can be shown from the doses in which farmer using only $100-150 \mathrm{~g} /$ tree/year for trees with age of 5-14 years. The values of $\mathrm{C} / \mathrm{N}$ ratio in the observed locations were around 9-12. The values showed that soil organic matter was already completely decompossed. Abdoellah (2013) reported that the ratio of $\mathrm{C} / \mathrm{N}$ less than 20 showed that $\mathrm{C}$ content was not too high than nitrogen, thus the mineralization happened and $\mathrm{N}$ releasing took place and absorbed by plants.

$\mathrm{K}$ content in this observed location in Panti, Sukorambi, Tanggul, and Silo subdistricts were at medium level with the value in the range of $\mathrm{K}$ was $0.5-1.2 \mathrm{me} / 100 \mathrm{~g}$. It showed that $\mathrm{K}$ content in all of the plantations surveyed were sufficient. $\mathrm{K}$ content in Sumber Baru subdistrict was high as the content more than $1.2 \mathrm{me} / 100 \mathrm{~g}$. $\mathrm{K}$ and $\mathrm{N}$ are important nutients for coffee to support production process (Abdoellah, 2013).

The range of soil acidity in the observed locations was around 4.2 to 5.3 classified as low. Soil nutrients will be available in optimal condition for coffee if soil $\mathrm{pH}$ in the range of 5.5-6.5 (Nur et al., 1998). Available nutrients are affected if low soil acidiy. Acidity of the soil significantly affect nutrient absorbtion by coffee plants. When soil acidity of a soil is low, soil nutrients which are more available for plants are $\mathrm{Fe}, \mathrm{Mn}, \mathrm{Cu}, \mathrm{Zn}$, and B. However, when soil acidity is high, then soil nutrients which available for plant are $\mathrm{K}, \mathrm{Ca}, \mathrm{S}$, and $\mathrm{Mg}$. Therefore, it is sonecessary to maintain equilibrium of soil acidity (Sari \& Abdoellah, 2015). Soil acidity has an important role for soil fertility because it affects soil CEC in which it is also able to be influenced by rainfall and high temperature (Tafakresnanto et al., 2012).

Soil calcium content in Silo and Tanggul subdistricts was at low level less than 5.3 $\mathrm{me} / 100 \mathrm{~g}$, whereas its content in Panti, Sumber Baru and Sukorambi subdistricts more than $10 \mathrm{me} / 100 \mathrm{~g}$, while in Silo and Tanggul $\mathrm{Ca}$ and $\mathrm{Mg}$ contents were low. Silo and Tanggul had low soil acidity which affected $\mathrm{Ca}$ and $\mathrm{Mg}$ availability to be low. Farmers in the observed locations did not use lime or dolomite therefore that the soil acidity was low. Dolomite and kieserite were main sources of $\mathrm{Ca}$ and $\mathrm{Mg}$. Further, Nurmegawati et al. (2013) reported that high rainfall caused base cation leaching to subsoil, and similar with soilbase complex, which 
resulted in $\mathrm{Ca}$ and $\mathrm{Mg}$ contents were lower in Silo and Tanggul subdistricts due to high rainfall rate.

Availability of $\mathrm{P}$ in all observed locations was higher and high soil organic performed by $\mathrm{C}$ content were also high more than $2 \%$. The soil in Sukorambi subdistrict performed organic $\mathrm{C}$ in amount of $1.99 \%$ that can be tolerated as closed to $2 \%$. Soil content of organic $\mathrm{C}$ was high enough that indicated the organic matter in the observed locations be fulfilled. Organic matter have a role for $P$ availability because organic acids can release P from soil fixation. Nursyamsi \& Setyorini (2009) reported that presence organic matter existence influenced $\mathrm{P}$ availablity. S nutrient in Tanggul and Silo subdistricts was higher which may due to soil acidity in Tanggul and Silo was low. $S$ nutrient was high in Tanggul and Silo subdistricts might be due to soil type, parent material, soil nutrients from shade trees and base cation leaching.

Based on the measurement of litterfall thickness in the field, litterfalls of Robusta coffee plantations in Panti subdistrict were thicker than those in other districts (Table 3). Litterfall thickness has positive correlation indirectly with soil fertility. Litterfalls from fallen leaves become natural compost materials which can be used directly by plants. The litterfall compost leads to high organic matter content in Robusta coffee plantations of Panti subdistrict. Data in Table 2 also explained that generally Robusta coffee plantations in Sukorambi, Sumber Baru, Tanggul, Silo, and Rambipuji subdistricts had organic matter content below standard value. It is known that organic matter requirements for coffee plant is $>3.5 \%$. From this condition, it is necessary to improve farm management where management of organic matters such as organic mulch and organic fertilizer can increase soil organic matter content. Use of organic matters is suggested in all locations of Robusta coffee plantations. They can be derived from composted plant litters and animal waste. It is recommended to use organic matters $20 \mathrm{~kg} /$ tree/year which can be applied to the silt pit so that the soil fertility is expected to be improved.

Based on observations in the field, types of shade trees and litterfall thickness in each study site were different. Each litterfall has different decomposition rate which indirectly affect soil fertility in each study site. Chemical content of each shade tree is also different and affect nutrient status in the soil at each location. Abdoellah (2013) reported that shade trees was one of soil nutrient source for coffee plant. It can be from prunning or litterfall used as green manure for coffee. Large difference among the plantations, shade trees used by Robusta coffee farmers were more varied with woody plants and fruits, but majority of farmers applied shade trees from woody and fruit trees. The difference of shade trees certainly affected diversity of soil fertility. Panti subdistrict, based on Table 2, seemed to have more fertile soil with indicators of high organic matter content. Its thick litter $(>3 \mathrm{~cm})$ was better than other locations, which had thinner litters. This could happen not only because the coffee

Table 3. Condition of smallholder's Robusta coffee plantations in the Jember districts

\begin{tabular}{llc}
\hline Location & \multicolumn{1}{c}{ Shade trees } & Altitude \\
\hline Panti & Durian, longan, avocado, albizia, timber, leucaena & $786 \mathrm{~m}$ asl. \\
Sukorambi & Teak, avocado, banana, coconut & $450 \mathrm{~m}$ asl. \\
Sumber Baru & Coconut, banana, albizia, teak & $361 \mathrm{~m}$ asl. \\
Tanggul & Albizia, coconut, banana & $326 \mathrm{~m}$ asl. \\
Silo & Banana, teak, coconut, pine, erythrina, leucaena & $569 \mathrm{~m}$ asl. \\
\hline
\end{tabular}


plants cultivated in the plantation, but also the amount of shade tree which contributed to litterfall covering soil surface. Production period of all locations was the same. Coffee will produce effectively until the age of 20 years. Thus, by looking at the age of coffee plants, all plantations had the same potential productivity.

Differences of soil fertility in Robusta coffee plantations of the observed locations were also influenced by others crop composed with coffee which contributed in determining nutrient content of the soil. Difference in shade trees provides recycle process and mineralization of different organic matters in soil. As a result, the status of nutrients in the soil will also be different (Purwanto, 2007).

\section{Sensory Profile}

Sensory analysis results showed variation of Robusta coffee sensory profiles produced by Robusta coffee farmers in the five subdistricts of Jember (Figure 1), even though characters of clean cup and uniformity were insignificantly different. It was caused by an already good processing (wet processing), thus the produced coffee flavor was clean from anything than coffee. Based on aspects of fragrance, flavor, aftertaste, salt/acid, bitter/sweet, mouthfeel, balance, and overall, the flavor profile was divided into three groups of quality. First, a group of fine Robusta coffee consisted of Robusta from Silo and Sukorambi subdistricts. This group had the best flavor profile, especially the characters of salt/acid, bitter/sweet, and mouthfeel, thus it got a good balance and preferences from the panelists. Based on the total score, Silo (82.5) and Sukorambi (82.0) Robusta coffees had the highest values (Table 4), and based on the classification of the SCAA both, included in the criteria of fine Robusta. Second, a group of good quality Robusta consisted of Robusta from Panti and Sumber Baru subdistricts. This group had an excellent flavor profile with a total score approaching 80.00 , so it had great potential to become fine Robusta. The process of good harvest (selective harvest with red ripe criteria) and good harvest sorting will improve the quality of produced Robusta coffee flavors. Third, a group of medium quality Robusta consisted of Robusta from Tanggul subdistrict. The total score of its coffee was 76.00, and based on SCAA testing the value was still classified as good quality coffee. However, when compared with the other two groups, the value was relatively low, therefore it was classified as medium quality Robusta. Flavor profile of the third group had the lowest score on all the characters tested.

Low quality of Robusta coffee flavors from Tanggul subdistrict when compared to the other four districts was supposedly caused by factors of altitude, plant age and post-harvest processes. Coffee planting locations in Tanggul subdistrict had the lowest elevation in comparison with other four subdistricts, as well as the plant age which was relatively young (five years).

Based on the data analysis of soil (Table 2) and the total score (Table 4), it showed that there was no correlation between flavor profile with environment fertility level. Silo subdistrict which had lower soil fertility level than the other four districts produced the best coffee flavor, although yet Table 5 showed no correlation between soil nutrition and coffee flavor.

The absence of relationship between soil fertility and Robusta coffee flavors was apparently due to external factors dominating the quality taste regarding each Robusta coffee farmer in the study site which had nearly practiced the same management plantation. Thus, the difference in flavor Robusta coffee 


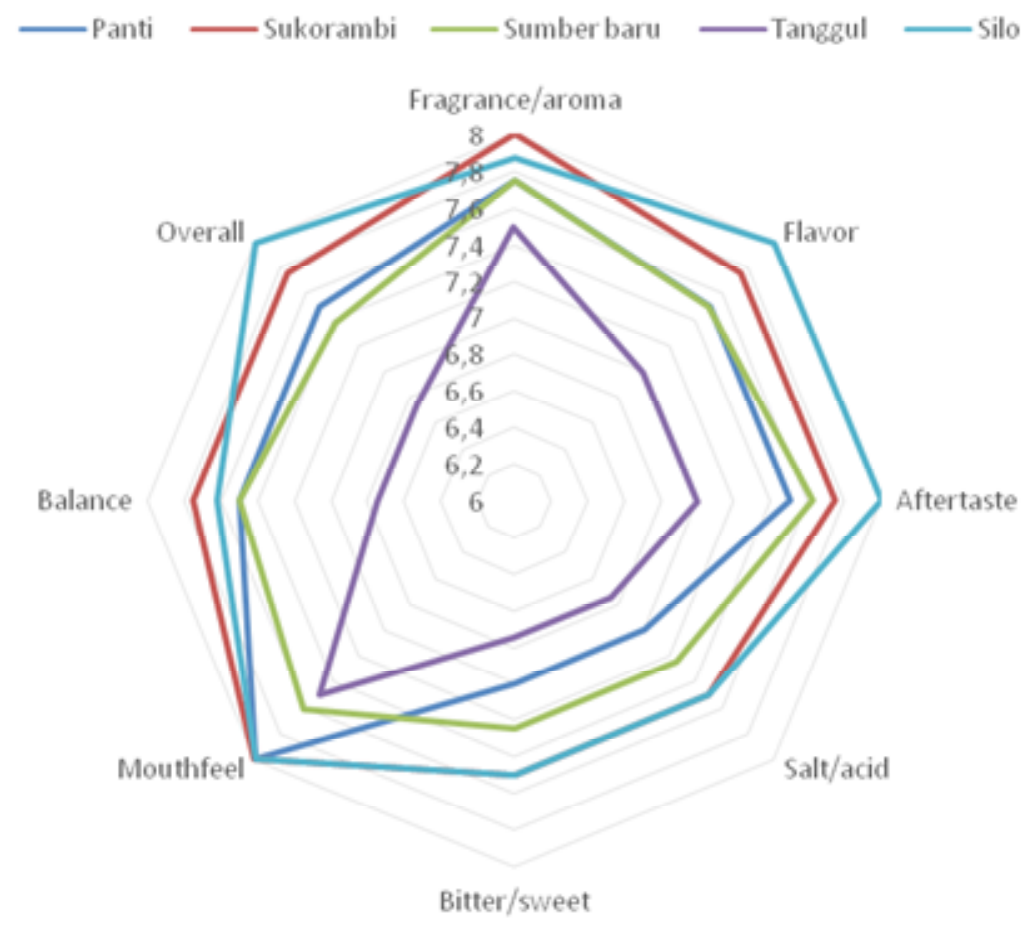

Figure 1. Sensory profile of Robusta coffee flavor obtained from five subdistricts in Jember

Table 4. Clean cup, uniformity, and total score of Robusta coffees from five subdistricts in Jember district

\begin{tabular}{lrcrrr}
\hline Caracter/subdustrict & Panti & Sukorambi & Sumberbaru & Tanggul & Silo \\
\hline Clean cup & 10 & 10 & 10 & 10 & 10 \\
Uniformity & 10 & 10 & 10 & 10 & 10 \\
Total score & 79.75 & 82.00 & 79.88 & 76.00 & 82.50 \\
\hline
\end{tabular}

can be caused by other factors, namely varieties, crop management and processing of coffee beans. The varieties used in each study site were assumed to be different and could not be identified because farmers dominantly used local clones instead of recommended superior ones. These differences may lead to different production of coffee flavors.

Beside these factors, there are climatic factors determining the level of Robusta coffee flavors (Abdoellah et al., 2000). The climate in Jember differs with other locations and depends on topography and vegetation. A study by Abdoellah (1989) proved that climate in northern part of Jember was more moist than that in its southern part. The climatic differences greatly affected flowering and fruit ripening of coffee in every location of plantation which eventually affected the coffee sensory profile.

Microclimate in each study site also depends on the condition of shade tree. Erdiansyah \& Yusianto (2012) explained that one of the determining factors of coffee flavor was light intensity. To produce optimal coffee flavor then medium intensity of light is required. Intensity of light in a plantation can be arranged with shade trees. Yadesa (2008) reported also that the shade tree type affected coffee taste. An optimal shade tree give maximum light so that fruit ripening would be perfect for it can affect coffee taste. This is consistent with study of Muschler (2001) which showed that shade tree slowed 
Table 5. Correlation of soil nutrition and coffee sensory profiles of coffee of smallholder farms in Jember district

\begin{tabular}{lrrrrrrrrrr}
\hline Parameter & \multicolumn{1}{c}{$\mathrm{C}$} & \multicolumn{1}{c}{$\mathrm{N}$} & \multicolumn{1}{c}{$\mathrm{C} / \mathrm{N}$} & $\mathrm{K}$ & $\mathrm{Ca}$ & $\mathrm{Mg}$ & $\mathrm{CEC}$ & Available $\mathrm{P}$ & $\mathrm{S}$ & $\mathrm{pH} \mathrm{H} \mathrm{H}_{2}$ \\
\hline Fragrance & -0.30 & -0.71 & -0.04 & 0.20 & 0.42 & 0.21 & -0.05 & 0.39 & -0.58 & 0.65 \\
& 0.63 & 0.18 & 0.98 & 0.75 & 0.48 & 0.73 & 0.94 & 0.51 & 0.31 & 0.23 \\
Flavor & -0.29 & -0.78 & 0.12 & 0.02 & 0.17 & 0.03 & -0.40 & 0.70 & -0.34 & 0.54 \\
& 0.64 & 0.12 & 0.85 & 0.98 & 0.79 & 0.97 & 0.51 & 0.19 & 0.58 & 0.35 \\
Aftertaste & -0.27 & -0.76 & 0.15 & 0.15 & 0.20 & 0.06 & -0.38 & 0.64 & -0.44 & 0.61 \\
& 0.67 & 0.13 & 0.81 & 0.81 & 0.74 & 0.93 & 0.53 & 0.25 & 0.46 & 0.28 \\
Salt/acid & -0.49 & -0.87 & -0.14 & 0.18 & 0.16 & -0.05 & -0.34 & 0.56 & -0.50 & 0.54 \\
& 0.40 & 0.06 & 0.82 & 0.77 & 0.80 & 0.93 & 0.58 & 0.33 & 0.39 & 0.35 \\
Bitter/sweet & -0.49 & -0.87 & -0.14 & 0.18 & 0.16 & -0.05 & -0.34 & 0.56 & -0.50 & 0.54 \\
& 0.40 & 0.06 & 0.82 & 0.77 & 0.80 & 0.93 & 0.58 & 0.33 & 0.39 & 0.35 \\
Mouthfeel & 0.06 & -0.42 & 0.33 & -0.13 & 0.45 & 0.36 & -0.01 & 0.47 & -0.24 & 0.55 \\
& 0.92 & 0.48 & 0.58 & 0.83 & 0.45 & 0.55 & 0.99 & 0.42 & 0.70 & 0.34 \\
Balance & -0.04 & -0.55 & 0.28 & 0.37 & 0.57 & 0.41 & 0.03 & 0.31 & -0.69 & 0.83 \\
& 0.95 & 0.34 & 0.65 & 0.54 & 0.39 & 0.50 & 0.96 & 0.61 & 0.20 & 0.08 \\
Overall & -0.20 & -0.72 & 0.19 & 0.03 & 0.26 & 0.13 & -0.31 & 0.69 & -0.37 & 0.59 \\
& 0.74 & 0.17 & 0.76 & 0.96 & 0.67 & 0.84 & 0.61 & 0.24 & 0.54 & 0.29 \\
\hline
\end{tabular}

fruit ripening which eventually affected coffee flavor.

Quality of coffee is actually difficult to be defined since it relates to taste or preferences. However, several influencing factors have been known, such as cultivar type, cultivation technique, geographic location, and applied post-harvest treatments (Carvalho, 1988; Mitchell, 1988; Barrels \& Jacquet, 1994). Research conducted by Lara-estrada \& Vaast (2006) showed that the effect of altitude on physical quality of seed planting, sensory quality, and biochemical composition of produced coffee beans were greater than the effect of cultivation practices such as providing shade tree and fertilization. Difference in temperature at different height is assumed to have a role in the process of flowering and ripening of coffee beans.

In addition to these factors, the balance of ions in soil can also affect physical quality and flavor of produced coffee. Recent research conducted by Castro-Tanzi et al. (2012) showed that the decrease in soil Ca content was associated with quality decrease especially flavor. In this study $\mathrm{Ca}$ had no correlation with flavor since soil Ca content in Silo subdistrict was low, while its coffee flavor had high value. Therefore, many factors are able to affect the coffee flavor.

\section{CONCLUSION}

Soil fertility in Jember Robusta coffee smallholder farms, especially smallholder's plantation in research locations showed that soil C organic was lower in Sukorambi subdistrict but medium in other locations. $\mathrm{N}$ was low in all subdistricts, whereas $\mathrm{K}$ was high in Sumber Baru subdistrict but in other locations was medium. $\mathrm{P}$ avalilability was higher in all locations. Calsium and magnesium were medium in Panti, Sukorambi, Sumber Baru, and Silo subdistricts. Soil acidity was low in all locations. The test scores of Robusta coffee flavor (based on SCAA) in Panti, Sukorambi, Sumber Baru, Tanggul, and Silo subdistricts were $79.75 ; 82 ; 79.88 ; 76$; and 82.5 , respectively. There were three groups of Robusta coffee sensory quality in Jember namely fine Robusta, good quality Robusta, and medium quality Robusta.

\section{ACKNOWLEDGEMENT}

This work was endorsed and supported by a grant from Dr. Teguh Wahyudi, Director of ICCRI. We would like also to express our sincere gratitude toward Dr. Surip Mawardi, and Ari Wahono, A.Md, respectively for their direction and assistance in conducting this study. 


\section{REFERENCES}

Abdoellah, S. (1989). Kajian tipe iklim dan intensitas curah hujan. Studi kasus di kota Jember, daerah Jember Selatan dan Malang Selatan. Pelita Perkebunan, 5, 17-24.

Abdoellah, S. (2013). Pengelolaan nutrisi tanaman terpadu di perkebunan kopi. Review Penelitian Kopi dan Kakao, 1, 24-39.

Abdoellah, S.; R. Hulupi \& Sulistyowati (2000). Hubungan antara cita rasa kopi Robusta dengan komposisi bahan tanam serta komponen lingkungan. Pelita Perkebunan, 16, 92-99.

Alley, M.M. \& B. Vanlauwe (2009). The Role of Fertilizers Integrated Plant Nutrient Management. International Fertilizer Association, Tropical Soil Biology and Fertility Institute of the International Centre for Tropical Agriculture. Paris.

Barel, M. \& M. Jacquet (1994). Coffee quality: its causes, appreciation and improvement. Plant Recherche Development, 1,5-10.

Carvalho, A. (1988). Principles and practice of coffee plant breeding for productivity and quality factors: coffea Arabica. p. 60-129. In: R.J. Clarke \& R. Macrae (Eds.), Coffee. Vol. 4: Agronomy. Elsevier Applied Science. London and New York.

Castro-Tanzi, S.; T. Dietsch.; N. Urena.; L. Vindas $\&$ M. Chandler (2012). Analysis of management and site factors to improve the sustainability of smallholder coffee production in Tarrazú, Costa Rica. Agriculture, Ecosystems \& Environment, 155, 172-181.

Ditjenbun (2011). Statistik Perkebunan Indonesia. KOPI. Direktorat Jenderal Perkebunan, Kementerian Pertanian. Jakarta.

Erdiansyah, N.P. \& Yusianto (2012). Hubungan intensitas cahaya dengan profil citarasa dan kadar kafein beberapa klon kopi Robusta. Pelita Perkebunan, 28, 14-22.
Kusmiati, A. \& R. Windiarti (2011). Analisis wilayah komoditas kopi di Indonesia. Jurnal Sosial Ekonomi Pertanian, 5, 47-48.

Lara-Estrada, L. \& P. Vaast (2006). Effects of altitude, shade, yield and fertilization on coffee quality (Coffea arabica L. var. Caturra) produced in agroforestry systems of the Northern Central Zones of Nicaragua. Journal of Food Science. 68, 2356-2361.

Mitchell, H.W. (1988). Cultivation and harvesting of the Arabica coffee tree. p. 9-43. In: R.J. Clarke \& R. Macrae (Eds.), Coffee. Vol. 4: Agronomy. London and New York: Elsevier Applied Science.

Muschler, R.G. (2001). Shades improves coffee quality in sub optimal coffee zona of Costa Rica. Agroforestry System, 51, 131-139.

Nalurita, S.; R.W. Asmarantaka \& S. Jahroh (2014). Analisis dayasaing dan strategi pengembangan agribisnis kopi Indonesia. Jurnal Agribisnis Indonesia, 2, 63-74.

Nur, A.M.; P. Rahardjo; R. Hulupi; S. Abdoellah; G. Supriyadji; B.O. Mubiyanto; Saidi; S. Wiryadiputra \& C. Ismayadi (1998). Pedoman Teknis Budidaya Tanaman Kopi (Coffea sp.). Pusat Penelitian Kopi dan Kakao Indonesia, Jember.

Nurmegawati; Afrizon \& D. Sugandi (2013). Kajian kesuburan tanah perkebunan karet rakyat di Provinsi Bengkulu. Jurnal Littri, 20, 17-26.

Nursyamsi, D. \& D. Setyorini (2009). Ketersediaan P tanah-tanah netral dan alkalin. Jurnal Tanah dan Iklim, 30, 25-37.

Purwanto; E. Handayanto; D. Suprayogo; J.B. Baon \& K. Hairiah (2007). Nitrifikasi potensial dan nitrogen mineral tanah pada sistem agroforestri kopi dengan berbagai pohon penaung. Pelita Perkebunan, 23, 38-56.

Puslitkoka (1998). Pedoman Teknis Budidaya Tanaman Kopi. Pusat Penelitian Kopi dan Kakao Indonesia. Jember. Indonesia. 
Putra, D.P. (2006). Jenis Tanah di Kawasan Hyang dan Raung Berdasarkan Topografi. Skripsi. Jurusan Tanah, Fakultas Pertanian, Universitas Jember. Jember.

Sari, N.P. \& S. Abdoellah (2015). Pengelolaan Hara Tanaman. p. 235-250.In: T. Wahyudi; Misnawi \& Pujiyanto (Eds.). KOPI: Sejarah, Botani, Proses Produksi, Pengolahan, Produk Hilir, dan Sistem Kemitraan. Pusat Penelitian Kopi dan Kakao Indonesia. Gadjah Mada University. Yogyakarta.

Snoeck, L. \& C. Lambot (2004). Crop maintenance. p. 976. In: J.N. Wintgens (Ed.) Coffee: Growing, Processing, Sustainable Production. Wiley-VCH Verlag GmbH \& Co. KgaA, Weinheim.

Surtinah (2013). Pengujian kandungan unsur hara dalam kompos yang berasal dari seresah tanaman jagung (Zea mays saccharata). Jurnal Ilmu Pertanian, $1,16-25$.

Tafakresnanto, C.; I. Las Darmawan \& B. Mulyanto (2012). Keterkaitan faktor pembentuk dan karakteristrik tanah sebagai pendekatan dalam pemetaan potensi sumberdaya lahan. Jurnal Tanah dan Iklim, 36, 23-33.
Sugiyanto; Sugiyono \& A. Wibawa (2005). Status hara tanah di perkebunan kopi dan kakao di Jawa Timur (Periode 20002005). Warta Pusat Penelitian Kopi dan Kakao Indonesia, 21, 120-124.

Wibawa, A. (1987). Tinjauan status hara tanah di beberapa kebun kopi di daerah Besuki. Pelita Perkebunan, 3, 14-22.

Yadesa, A.; J. Burkhardt; M. Denich; T. Woldemariam; E. Bekele \& H. Goldbach (2008). Effect of different indigeneous shade tree on the quality of wild Arabica coffee in the affromontane rainforest of Ethiopia. Proceeding $22^{\text {nd }}$ ASIC International Conference on Coffee Science (ASIC). p. 1227-1233. Campinas, Brazil.

Zahrosa, D.B. (2011). Prospek Pengembangan dan Strategi Pemasaran Komoditas Kopi Robusta Rakyat di Kabupaten Jember. Skripsi. Jurusan Sosial Ekonomi Pertanian, Fakultas Pertanian, Universitas Jember. Jember.

$* * 0 * *$ 